\title{
Yield of comparative genomic hybridization microarray in pediatric neurology practice
}

Shibalik Misra, MBBS/MPhil, Greg Peters, PhD, Elizabeth Barnes, BAppSc/MStat, Simone Ardern-Holmes, PhD, Richard Webster, FRACP, Christopher Troedson, FRACP, Shekeeb S. Mohammad, PhD, Deepak Gill, FRACP, Manoj Menezes, PhD, Sachin Gupta, FRACP, Peter Procopis, FRACP, Jayne Antony, FRACP, Manju A. Kurian, PhD, and Russell C. Dale, PhD

Neurol Genet 2019;5:e367. doi:10.1212/NXG.0000000000000367

\section{Abstract \\ Objective}

The present study investigated the diagnostic yield of array comparative genomic hybridization $(\mathrm{aCGH})$ in a large cohort of children with diverse neurologic disorders as seen in child neurology practice to test whether pathogenic copy number variants (CNVs) were more likely to be detected in specific neurologic phenotypes.

\section{Methods}

A retrospective cross-sectional analysis was performed on 555 children in whom a genetic etiology was suspected and who underwent whole-genome aCGH testing between 2006 and 2012. Neurologic phenotyping was performed using hospital medical records. An assessment of pathogenicity was made for each $\mathrm{CNV}$, based on recent developments in the literature.

\section{Results}

Forty-seven patients were found to carry a pathogenic $\mathrm{CNV}$, giving an overall diagnostic yield of $8.59 \%$. Certain phenotypes predicted for the presence of a pathogenic CNV, including developmental delay (odds ratio [OR] 3.69 [1.30-10.51]), cortical visual impairment (OR 2.73 [1.18-6.28]), dysmorphism (OR 2.75 [1.38-5.50]), and microcephaly (OR 2.16 [1.01-4.61]). The combination of developmental delay/intellectual disability with dysmorphism and abnormal head circumference was also predictive for a pathogenic CNV (OR 2.86 [1.02-8.00]). For every additional clinical feature, there was an increased likelihood of detecting a pathogenic CNV (OR 1.18 [1.01-1.38]).

\section{Conclusions}

The use of aCGH led to a pathogenic finding in $8.59 \%$ of patients. The results support the use of aCGH as a first tier investigation in children with diverse neurologic disorders, although wholegenome sequencing may replace aCGH as the detection method in the future. In particular, the yield was increased in children with developmental delay, dysmorphism, cortical visual impairment, and microcephaly.

\section{Correspondence}

Dr. Misra

smis4001@uni.sydney.edu.au

From the Kids Neuroscience Centre (S.M., R.D.), the Children's Hospital at Westmead, Faculty of Medicine and Health, the University of Sydney; Department of Clinical Genetics (G.P.) at the Children's Hospital at Westmead; Kids Research Institute at Westmead (E.B.); TY Nelson Department of Neurology and Neurosurgery at the Children's Hospital at Westmead Sydney (S.A.-H., R.W., C.T., S.S.M., D.G., M.M., S.G., P.P., J.A., R.C.D.), New South Wales, Australia; and Institute of Child Health (M.K.), University College London, UK. 


\section{Glossary}

aCGH = array comparative genomic hybridization; ASD = autism spectrum disorder; CGH = comparative genomic hybridization; $\mathbf{C H W}=$ Children's Hospital at Westmead; $\mathbf{C I}=$ confidence interval; $\mathbf{C N V}=$ copy number variant; $\mathbf{O R}=$ odds ratio.

Array comparative genomic hybridization $(\mathrm{aCGH})$ is a genetic technology used to identify copy number variants (CNVs). A CNV is a duplicated or deleted segment of DNA, greater than $1 \mathrm{~kb}$ in size, which is observed to vary in the comparison of 2 or more genomes. ${ }^{1}$ Early studies demonstrated that CNVs provided an important contribution to genetic diversity among healthy individuals. ${ }^{2,3}$ However, microdeletions and microduplications also have the potential to cause neurologic disorders by altering gene expression.

A genetic etiology is often suspected in children who present with undiagnosed neurologic disorders. In a proportion of children, the underlying cause is a pathogenic microdeletion or microduplication. The utility of aCGH has been extensively studied in children with developmental delay, intellectual disability, and autism, where a diagnostic yield between $7.8 \%$ and $18.6 \%$ has been reported. ${ }^{4-23}$ Additional studies have focused on children with epilepsy, showing a diagnostic yield between $4.1 \%$ and $10.9 \% .{ }^{24-28}$ However, the diagnostic yield in children presenting to pediatric neurology departments with a broader set of phenotypes remains to be established. Therefore, we examined the diagnostic yield of aCGH in a referred pediatric neurology cohort. In particular, we aimed to identify whether specific neurologic phenotypes, either in isolation or combination, increased the odds ratio (OR) of finding a pathogenic $\mathrm{CNV}$ with aCGH technology.

\section{Methods}

\section{Patient selection}

This study was performed at the T.Y. Nelson Department of Neurology and Neurosurgery at the Children's Hospital at Westmead (CHW) in Sydney, Australia. This is the major referral facility for children with neurologic disorders in the Western Sydney region. A retrospective cross-sectional analysis was conducted on 555 sequential children who had been investigated with aCGH under the care of 11 consultant neurologists (R.D., S.A.H., C.T., S.G., M.M., R.W., P.P., R.O., S.M., D.G., and J.A.) in the department between January 2006 and December 2012. The referral for aCGH testing in each case had been prompted by the presentation of a child with a neurologic disorder of unknown etiology but suspected to be of genetic origin. The list of patients who had been investigated with aCGH was obtained from the clinical genetics department of the hospital. Patients were excluded from the study if there was no available hard copy or electronic medical record outlining their clinical phenotype or if the hard copy notes had been stored in an off-site location and could not be retrieved. The study included children who had been investigated during inpatient admissions and children seen as outpatients.

\section{Data collection}

The medical records were reviewed to gather information on clinical phenotype, findings on MRI, results of ancillary testing such as EEG/nerve conduction study/muscle biopsy, and specialist consultations. This information was captured in 94 clinical data points (see supplementary text, links.lww.com/ NXG/A188). In particular, the outcome of comparative genomic hybridization (CGH) microarray testing was noted, including parental and sibling results wherever available, to determine inheritance. Medical records were in the form of hard copy files or online documentation in the institutional electronic medical record system known as PowerChart. The accuracy of the data was corroborated through intensive review by the treating consultant neurologist in conjunction with the data collector (S.M.), with any discrepancies allayed through discussion and further perusal of notes where appropriate. The purpose of this was to cross-check for accuracy of phenotyping. For further information on the clinical phenotyping, and definitions used to consider a clinical feature as being present, please refer to the supplementary text.

\section{Platforms used for aCGH testing}

The aCGH platforms used included SurePrint G3 Custom CGH Microarray $4 \times 180 \mathrm{~K}$, ISCA $8 \times 60 \mathrm{~K}$ design, and bacterial artificial chromosome Array $4 \mathrm{~K}$, as per the manufacturer's instructions. Data analysis was undertaken using Agilent Technologies software, with routine settings as follows: aberration algorithm: ADM-2; threshold 6.7; neutralization: $\mathrm{ON}$; bin size: 10; centralization threshold 6.0 ; fuzzy zero: $\mathrm{ON}$; combine replicates (intra-array): $\mathrm{ON}$; genome hg18; aberration filters: $\min$ Probes $=5$ AND minAvgAbsLogRatio $=0.25$ AND maxAberrations $=30$ AND percentPenetrance $=0$; expand non unique probes: OFF.

\section{Interpretation of CNV pathogenicity}

As mentioned previously, healthy individuals are known to carry polymorphic CNVs that are effectively benign, which need to be segregated from truly pathogenic CNVs. The CGH microarray results were first distinguished according to whether they included a reportable CNV of potential clinical significance. For those patients with a $\mathrm{CNV}$ of potential clinical significance, the report stated the size of the CNV, its location in the genome, whether there were any OMIM genes deleted, and a preliminary conclusion was offered regarding the degree of pathogenicity, in the view of the supervising scientist. The CNV was provisionally described as either 
"benign," "likely benign," "a variant of uncertain significance," or "pathogenic". Further reassessment of CNV pathogenicity was performed in 2017-2018 based on the most comprehensive algorithm for $\mathrm{CNV}$ interpretation to date, published by Beaudet et al. ${ }^{29}$ in Nature Genetics. In brief, CNVs were graded into 5 categories of pathogenicity:

- Category 1: severe disability, very high or complete penetrance, de novo inheritance, and nil reproduction

- Category 2: intermediate severity of disability, $50 \%-90 \%$ penetrance, either de novo or inherited genetic defect, and reduced reproduction

- Category 3: mild or absent disability, $5 \%-100 \%$ penetrance, largely inherited transmission of genetic defect, and essentially normal reproduction

- Category 4: Mild or absent disability, 5\%-50\% penetrance, inherited transmission of genetic defect in virtually all cases, and essentially normal reproduction

- Category 5: nil disability, either de novo or inherited genetic defect, and normal reproduction

The University of California, Santa Cruz genome browser was used to facilitate grading. ${ }^{30}$ The browser allowed for comparison with CNVs reported in other genomic databases (Database of Genomic Variants, ExAC, ClinGen, and DECIPHER, UK) and included data on polymorphic CNVs, map locations, OMIM gene content, phenotypic associations, severity of disease, penetrance, and information on established microdeletion and microduplication syndromes. In this study, all genome map references were based on the February 2009 genome assembly (build GRCh37/hg19).

We considered categories 1, 2, and 3 to be "pathogenic" and categories 4 and 5 to be "benign." We took Beaudet category 3 as the lower limit of "pathogenic" because this category contained CNVs that have traditionally been considered pathogenic, whereas there were no such CNVs in category 4. The archetypal example of a category $3 \mathrm{CNV}$ is the microduplication at locus $17 \mathrm{p} 12$, containing the gene PMP22, causing Charcot-Marie-Tooth 1A neuropathy. This microduplication, known to be causative of the phenotype, is Beaudet category 3 because there is mild or absent disability, $5 \%-100 \%$ penetrance, established inheritance of genetic defect, and essentially normal reproduction.

Patients who manifested whole chromosomal aneuploidies such as trisomy 21, Klinefelter syndrome 47XXY, and Turner syndrome 45X deviated from the outcome of interest (namely chromosomal microdeletions or microduplications), and they were therefore excluded from analysis.

\section{Statistical analysis}

The SAS 9.4 software was used to analyze the data. Associations between clinical phenotypes and pathogenic CNVs on aCGH testing were established using $\chi^{2}$ tests and logistical regression. Results were described using ORs and 95\% confidence intervals (CIs). ORs for predicting a pathogenic $\mathrm{CNV}$ were obtained for clinical features in isolation and in combination. The latter combinations were chosen before statistical analysis, and these combinations of clinical features were deemed to reflect common combinations of neurologic disorders in the pediatric cohort.

\section{Standard protocol approvals, registrations, and patient consents}

The ethics committee at the CHW, Sydney, granted approval for this study (Ethics Number-LNR/14/SCHN/112). The study did not require individual patient registration or consent, and data were collected in a deidentified manner.

\section{Data availability}

Anonymized data not published in the content of this article will be shared upon request from any qualified investigator.

\section{Results}

The cohort comprised 555 children with neurologic disorders, of which 316 were boys and 239 were girls. The mean age at the time of data collection was 10.01 years (age range $0.25-23$ years at data collection). The frequency of neurologic phenotypes in our cohort is shown in table 1.

There was a notably high prevalence of global developmental delay $(n=359)$, intellectual disability $(n=277)$, epilepsy $(n=$ $272)$, autism spectrum disorder (ASD) $(n=92)$, movement disorders $(\mathrm{n}=94)$, and psychiatric comorbidity $(\mathrm{n}=121)$. There was an approximately even distribution of developmental delay into mild $(\mathrm{n}=157)$, moderate $(\mathrm{n}=135)$, and severe $(n=129)$ phenotypes. A relatively even spread was also seen for mild $(\mathrm{n}=76)$, moderate $(\mathrm{n}=100)$, and severe ( $\mathrm{n}$ $=101$ ) intellectual disability. Approximately $30 \%$ of the cohort had an abnormal brain MRI, with white matter abnormalities $(n=108)$ and cerebellar pathologies $(n=55)$ being the most common findings.

\section{Diagnostic yield}

As shown in table 2, there were 132 patients reported as carrying a $\mathrm{CNV}$ in the form of a microdeletion, microduplication, or another complex combination of the two. Where available, parental testing was reviewed to clarify whether the CNV occurred de novo. Forty-seven of 132 patients were considered to have a pathogenic CNV (category 1 to $3 \mathrm{CNVs}$ ). In contrast, there were 79 patients for whom the $\mathrm{CNV}$ detected was considered benign and therefore noncontributory to the patient phenotype (category 4 and 5 CNVs).

By taking the 47 patients with pathogenic CNVs from 547 patients with available data ( 8 with omitted data), the overall absolute diagnostic yield was $8.59 \%$. For a full list of the 47 patients with pathogenic CNVs, please refer to table e-1, table e-2, and table e-3 in supplementary text 1 (links.lww.com/ NXG/A188). A description of CNV location and clinical phenotype is provided. 
Table 1 Frequency of neurologic phenotypes for the 555 patients

\begin{tabular}{|c|c|}
\hline Phenotype & Frequency (\% of cohort) \\
\hline Parental consanguinity & $30(5.41)$ \\
\hline Positive first-degree family history & $151(27.21)$ \\
\hline Developmental delay & $421(75.86)$ \\
\hline Global & $359(64.68)$ \\
\hline Significant language delay & $211(38.02)$ \\
\hline Motor delay in isolation & $22(3.96)$ \\
\hline Language delay in isolation & $37(6.67)$ \\
\hline \multicolumn{2}{|l|}{ Severity of developmental delay } \\
\hline Mild & $157(28.29)$ \\
\hline Moderate & $135(24.32)$ \\
\hline Severe & $129(23.24)$ \\
\hline Autistic spectrum disorder & $92(16.58)$ \\
\hline Intellectual disability & $277(49.91)$ \\
\hline Mild & 76 (13.69) \\
\hline Moderate & $100(18.02)$ \\
\hline Severe/profound & $101(18.20)$ \\
\hline Cortical visual impairment & $43(7.75)$ \\
\hline Sensorineural hearing impairment & $30(5.41)$ \\
\hline Dysmorphism & $75(13.51)$ \\
\hline Neurocutaneous syndrome & $11(1.98)$ \\
\hline Abnormal head circumference & $95(17.12)$ \\
\hline Microcephaly & $67(12.07)$ \\
\hline Macrocephaly & $28(5.05)$ \\
\hline Epilepsy & $272(49.01)$ \\
\hline Focal & $133(23.96)$ \\
\hline Generalized & $192(34.59)$ \\
\hline Myoclonic & $39(7.03)$ \\
\hline Tonic & $57(10.27)$ \\
\hline Status epilepticus & $57(10.27)$ \\
\hline Epileptic encephalopathy & $65(11.71)$ \\
\hline Medically refractory seizures & $75(13.51)$ \\
\hline Ataxia or cerebellar syndrome & $46(8.29)$ \\
\hline Movement disorder & $94(16.94)$ \\
\hline Tourette syndrome & $6(1.08)$ \\
\hline Other tic disorder & $3(0.54)$ \\
\hline Chorea & $23(4.14)$ \\
\hline Dystonia & $60(10.81)$ \\
\hline Myoclonus & $9(1.62)$ \\
\hline
\end{tabular}

Table 1 Frequency of neurologic phenotypes for the 555 patients (continued)

\begin{tabular}{|c|c|}
\hline Phenotype & Frequency ( $\%$ of cohort) \\
\hline Tremor & $24(4.32)$ \\
\hline Psychiatric comorbidity & $121(21.80)$ \\
\hline Attention-deficit hyperactivity disorder & $85(15.32)$ \\
\hline Depression & $11(1.98)$ \\
\hline Anxiety & $34(6.13)$ \\
\hline Obsessive compulsive disorder & $5(0.90)$ \\
\hline Psychosis & $2(0.36)$ \\
\hline Oppositional defiant disorder & $19(3.42)$ \\
\hline Abnormality of tone & $292(52.61)$ \\
\hline Hypotonia & $142(25.59)$ \\
\hline Hypertonia & $84(15.14)$ \\
\hline Spasticity & $66(11.89)$ \\
\hline Cerebral palsy & $73(13.15)$ \\
\hline Hemiplegic & $2(0.36)$ \\
\hline Diplegic & $13(2.34)$ \\
\hline Quadriplegic & $14(2.52)$ \\
\hline Dyskinetic (dystonic/choreoathetoid) & $16(2.88)$ \\
\hline Ataxic & $7(1.26)$ \\
\hline Hypotonic & $8(1.44)$ \\
\hline Quadriplegic and dyskinetic & $6(1.08)$ \\
\hline Diplegic and ataxic & $1(0.18)$ \\
\hline Worster-Drought phenotype & $1(0.18)$ \\
\hline Unclear/unclassified & $5(0.90)$ \\
\hline Weakness not otherwise specified & $42(7.57)$ \\
\hline Myopathy & $14(2.52)$ \\
\hline Neuropathy & $17(3.06)$ \\
\hline Spastic hereditary paraplegia & $7(1.26)$ \\
\hline Abnormal brain MRI & $167(30.09)$ \\
\hline Malformation & $29(5.23)$ \\
\hline Dysplasia & $36(6.49)$ \\
\hline Ventricular pathology & $28(5.05)$ \\
\hline Cerebellar pathology & $55(9.91)$ \\
\hline White matter abnormality & $108(19.46)$ \\
\hline Abnormal spine MRI & $15(2.70)$ \\
\hline Abnormal EEG & $238(42.88)$ \\
\hline Seen by a geneticist & $219(39.46)$ \\
\hline
\end{tabular}

The number and percentage of each feature is presented. 
Table 2 Diagnostic yield of aCGH testing

\begin{tabular}{ll}
\hline aCGH testing & Result \\
\hline Number of patients studied & 555 \\
\hline No reported CNV & 421 \\
\hline Reported CNV & 132 \\
\hline Pathogenic aCGH result & 47 \\
\hline Beaudet category 1 & 8 \\
\hline Beaudet category 2 & 27 \\
\hline Beaudet category $\mathbf{3}$ & 12 \\
\hline Benign aCGH result & 79 \\
\hline Beaudet category 4 & 55 \\
\hline Beaudet category 5 & 24 \\
\hline Data omitted from analysis & 8 \\
\hline Excluded (whole chromosomal aneuploidies) & 6 \\
\hline Insufficient DNA & 1 \\
\hline Test canceled & 1 \\
\hline
\end{tabular}

Abbreviations: $\mathrm{aCGH}=$ array comparative genomic hybridization; $\mathrm{CNV}=$ copy number variant.

\section{OR for predicting a pathogenic CNV}

Given that the diagnostic yield of aCGH was $8.59 \%$, we next determined the clinical features that were predictive of a pathogenic $\mathrm{CNV}$ using univariate analysis and ORs. ORs could not be calculated when no pathogenic $\mathrm{CNV}$ was detected in association with the phenotype in question, as was seen for parental consanguinity, depression, myopathy, and spastic hereditary paraplegia.

As shown in table 3, a number of neurologic phenotypes were associated with pathogenic CNVs on aCGH testing. Developmental delay showed OR 3.69 (1.30-10.51), cortical visual impairment OR 2.73 (1.18-6.28), dysmorphism OR 2.75 (1.38-5.50), and microcephaly OR 2.16 (1.01-4.61).

Although table 3 demonstrated analysis on clinical features in isolation, we acknowledged that this was the exception in clinical practice. It was more common for patients to express multiple clinical features simultaneously. Therefore, we determined the OR of predicting a pathogenic $\mathrm{CNV}$ for the more common combinations of neurologic phenotypes.

As illustrated in table 4, the combination of developmental delay or intellectual disability with dysmorphism predicted for a pathogenic $\mathrm{CNV}$ on aCGH testing, with OR 2.86 (1.43-5.72). A similar combination of developmental delay or intellectual disability with dysmorphism and abnormal head circumference also predicted for a pathogenic $\mathrm{CNV}$ on aCGH testing, with OR 2.86 (1.02-8.00).
We had hypothesized that an increasing number of clinical features in an individual patient would increase the likelihood of detecting a pathogenic $\mathrm{CNV}$ on aCGH testing. The 17 broad clinical data points considered in our study, comprising the most common features on presentation, were positive family history, developmental delay, intellectual disability, ASD, cortical visual impairment, sensorineural hearing loss, dysmorphism, neurocutaneous lesions, abnormal head circumference, epilepsy, ataxia or cerebellar syndrome, movement disorder, psychiatric comorbidity, cerebral palsy, myopathy, neuropathy, and abnormal karyotype or MRI. There were 18 patients with none of these clinical features, 63 with 1 clinical feature, 86 with 2 clinical features, 98 with 3 clinical features, 107 with 4 clinical features, 77 with 5 clinical features, 61 with 6 clinical features, 25 with 7 clinical features, 6 with 8 clinical features, 2 with 9 clinical features, 2 with 10 clinical features, and 1 patient with 11 clinical features in combination (maximum). Logistic regression analysis showed that for every additional clinical feature in an individual patient, there was an OR $1.18(1.01-1.38, p=0.03)$ for detecting a pathogenic $\mathrm{CNV}$ on aCGH testing.

\section{Discussion}

Our experience with whole-genome aCGH returned a diagnostic yield of $8.59 \%$, falling on the lower end of the range reported in the literature. However, this study analyzed CNVs using a graded level of pathogenicity. It is now well established that microdeletions and microduplications cannot be adjudicated to a dichotomous outcome of "normal" and "abnormal." The classification system adopted here, first presented by Beaudet, ${ }^{29}$ was the most comprehensive algorithm for interpretation at the time of this study. Based on our didactic experience with the Beaudet algorithm, we strongly advocate for its use as a standardized approach in future studies. Indeed, table 2 exhibits that only 47 of the $132 \mathrm{CNVs}$ detected by our genetics laboratory were ultimately considered "pathogenic." As mentioned previously, these were the variants that fell into Beaudet categories 1-3. The objectivity of the Beaudet interpretation protocol is reflected by the fact that almost two-thirds of our laboratory-reported CNVs were classified as benign.

Our study cohort comprised patients with varying combinations of neurologic features, each of which could increase or decrease the diagnostic yield of aCGH testing if examined in isolation. One group of investigators reported compelling evidence that ASD was associated with a reduction in diagnostic yield on aCGH testing. For patients with ASD alone, their diagnostic yield for a pathogenic $\mathrm{CNV}$ was $4.4 \%$. In their entire cohort, the diagnostic yield was $8.6 \%$, which increased to $12.5 \%$ when ASD was removed as an indication for testing. ${ }^{20}$ Our results for ASD demonstrated an OR 0.32 (95\% CI $0.10-1.05)$ in predicting for a pathogenic CNV. Although this did not provide statistical evidence, the trend was similarly toward a reduction in diagnostic yield. In addition, our cohort had 73 patients with cerebral palsy (13.15\% of cohort). The etiology of cerebral palsy can be a perinatal hypoxic insult or 
Table 3 OR of predicting a pathogenic result on array comparative genomic hybridization for neurologic phenotypes in isolation

\begin{tabular}{|c|c|c|}
\hline Clinical feature & OR $(95 \% \mathrm{Cl})$ & $\begin{array}{l}p \\
\text { Value }\end{array}$ \\
\hline Parental consanguinity & - & - \\
\hline Positive first-degree family history & $1.17(0.61-2.26)$ & 0.64 \\
\hline Developmental delay & $3.69(1.30-10.51)^{a}$ & 0.01 \\
\hline Global & $1.87(0.93-3.77)$ & 0.07 \\
\hline Significant language delay & $1.12(0.61-2.05)$ & 0.72 \\
\hline Motor delay in isolation & $0.50(0.07-3.77)$ & 0.49 \\
\hline Language delay in isolation & $2.29(0.90-5.83)$ & 0.07 \\
\hline Autism spectrum disorder & $0.32(0.10-1.05)$ & 0.05 \\
\hline Intellectual disability & $1.28(0.70-2.33)$ & 0.42 \\
\hline Cortical visual impairment & $2.73(1.18-6.28)^{a}$ & 0.01 \\
\hline Sensorineural hearing impairment & $0.78(0.18-3.38)$ & 0.74 \\
\hline Dysmorphism & $2.75(1.38-5.50)^{\mathrm{a}}$ & 0.003 \\
\hline Neurocutaneous syndrome & $2.42(0.51-11.57)$ & 0.25 \\
\hline \multicolumn{3}{|l|}{ Abnormal head circumference } \\
\hline Microcephaly & $2.16(1.01-4.61)^{\mathrm{a}}$ & 0.05 \\
\hline Macrocephaly & $1.54(0.44-5.38)$ & 0.50 \\
\hline Epilepsy & $0.83(0.45-1.51)$ & 0.54 \\
\hline Focal & $0.63(0.29-1.38)$ & 0.24 \\
\hline Generalized & $1.08(0.58-2.01)$ & 0.81 \\
\hline Status epilepticus & $0.80(0.28-2.32)$ & 0.68 \\
\hline Epileptic encephalopathy & $1.12(0.45-2.74)$ & 0.81 \\
\hline Medically refractory seizures & $0.77(0.30-2.03)$ & 0.60 \\
\hline Ataxia or cerebellar syndrome & $1.33(0.50-3.55)$ & 0.56 \\
\hline Movement disorder & $1.19(0.55-2.55)$ & 0.66 \\
\hline Chorea & $2.36(0.77-7.24)$ & 0.12 \\
\hline Dystonia & $2.13(0.97-4.66)$ & 0.05 \\
\hline Tremor & $0.50(0.07-3.77)$ & 0.49 \\
\hline Psychiatric comorbidity & $0.61(0.27-1.41)$ & 0.24 \\
\hline $\begin{array}{l}\text { Attention-deficit hyperactivity } \\
\text { disorder }\end{array}$ & $0.64(0.25-1.68)$ & 0.36 \\
\hline Depression & - & - \\
\hline Anxiety & $1.07(0.31-3.64)$ & 0.92 \\
\hline Opposition defiant disorder & $0.62(0.08-4.75)$ & 0.64 \\
\hline
\end{tabular}

Abnormality of tone

\begin{tabular}{lcc}
\hline Hypotonia & $1.10(0.56-2.15)$ & 0.78 \\
\hline Hypertonia & $1.79(0.87-3.67)$ & 0.11 \\
\hline Spasticity & $1.31(0.56-3.05)$ & 0.53 \\
\hline
\end{tabular}

Table 3 OR of predicting a pathogenic result on array comparative genomic hybridization for neurologic phenotypes in isolation (continued)

\begin{tabular}{lll}
\hline Clinical feature & OR $(95 \% \mathrm{Cl})$ & $\begin{array}{l}\boldsymbol{p} \\
\text { Value }\end{array}$ \\
\hline Cerebral palsy & $1.37(0.61-3.07)$ & 0.44 \\
\hline Myopathy & - & - \\
\hline Neuropathy & $2.37(0.66-8.55)$ & 0.18 \\
\hline Spastic hereditary paraplegia & - & - \\
\hline Abnormal brain MRI & $1.20(0.64-2.27)$ & 0.56 \\
\hline Abnormal spine MRI & $0.75(0.10-5.87)$ & 0.79 \\
\hline Abnormal EEG & $0.89(0.49-1.64)$ & 0.71 \\
\hline
\end{tabular}

Abbreviations: $\mathrm{Cl}=$ confidence interval; $\mathrm{OR}=$ odds ratio.

${ }^{a}$ Indicates statistical significance.

trauma to the CNS during early development. Such etiologies are not intuitively genetic and thus may also have contributed to a low diagnostic yield for cerebral palsy.

Only one other group based in Melbourne, Australia, have investigated the diagnostic yield of aCGH in a broad cohort of children seen in the pediatric neurology setting, similar to this study. ${ }^{31}$ Their sample size of 215 included patients with epilepsy, movement disorders, neuromuscular conditions, microcephaly, and congenital malformations. In accordance with our study, they found pathogenic CNVs in all the above neurologic phenotypes, with a diagnostic yield of at least $9.3 \%$. However, they particularly emphasized the utility of aCGH in patients with severe epilepsy and epileptic encephalopathy, in whom they achieved their highest diagnostic yield of approximately $21 \%$. In contrast, epilepsy did not predict for pathogenic CNVs in our study, returning an OR 0.83 (95\% CI 0.45-1.51). Epileptic encephalopathy was also insignificant with OR 1.12 (95\% CI 0.45-2.74). Further studies are needed to ascertain the relative contribution of point mutations vs $\mathrm{CNVs}$ in genetic epilepsies and epileptic encephalopathies.

Array CGH technology is now used on a routine basis for the investigation of various neurologic disorders. However, it is unclear which patients are likely to benefit most from this technology and how exactly the test should be directed and interpreted. In clinical practice, whole-genome CGH microarray platforms are generally indicated for the investigation of patients with developmental delay, intellectual disability, ASD, or at least 2 congenital abnormalities. We identified pathogenic CNVs in patients of all neurologic phenotypes, not just those with developmental delay, intellectual disability, autism, and congenital malformations. Certain phenotypes were identified that showed an increased correlation with pathogenic CNVs. These were developmental delay (OR 3.69 [95\% CI 1.30-10.51]), cortical visual impairment (OR 2.73 [95\% CI 1.18-6.28]), dysmorphism (OR 2.75 [95\% CI 1.38-5.50]), and microcephaly 
Table 4 OR of predicting a pathogenic result on array comparative genomic hybridization for neurologic phenotypes in combination

\begin{tabular}{|c|c|c|}
\hline Combination of phenotypes & OR $(95 \% \mathrm{Cl})$ & $p$ Value \\
\hline Developmental delay/intellectual disability and dysmorphism & $2.86(1.43-5.72)^{a}$ & 0.002 \\
\hline Developmental delay/intellectual disability and epilepsy & $1.06(0.58-1.95)$ & 0.85 \\
\hline Developmental delay/intellectual disability and autism spectrum disorder & $0.35(0.11-1.15)$ & 0.07 \\
\hline Developmental delay/intellectual disability I psychiatric comorbidity & $0.70(0.29-1.71)$ & 0.44 \\
\hline Developmental delay/intellectual disability and movement disorder & $1.56(0.72-3.37)$ & 0.26 \\
\hline Developmental delay/intellectual disability and epilepsy and movement disorder & $0.67(0.16-2.90)$ & 0.59 \\
\hline Developmental delay/intellectual disability and cerebral palsy & $1.42(0.64-3.18)$ & 0.39 \\
\hline Developmental delay/intellectual disability and dysmorphism and abnormal head circumference & $2.86(1.02-8.00)^{\mathrm{a}}$ & 0.04 \\
\hline Developmental delay/global developmental delay and intellectual disability and epilepsy & $0.67(0.33-1.39)$ & 0.28 \\
\hline
\end{tabular}

Abbreviations: $\mathrm{Cl}=$ confidence interval, $\mathrm{OR}=$ odds ratio.

a Indicates statistical significance.

(OR 2.16 [95\% CI 1.01-4.61]). Furthermore, we have shown that the combination of developmental delay or intellectual disability with dysmorphism and abnormal head circumference also predicted for the presence of a pathogenic CNV (OR 2.86 [95\% CI 1.02-8.00]). For every additional clinical feature recorded in our study, there was an OR 1.18 (95\% CI 1.01-1.38, $p$-value 0.03$)$ for finding a pathogenic $\mathrm{CNV}$ on aCGH testing, suggesting that aCGH should be strongly considered in patients with complex neurologic phenotypes.

Although aCGH will likely be replaced by whole-exome and genome sequencing as a method of detecting microdeletions and duplications in the future, regardless of detection method the associations described in the present study will remain relevant. Furthermore, although we have defined clinical associations of pathogenic CNVs detected with aCGH, our study did not capture how these findings resulted in a change in clinical practice, such as an end to the diagnostic odyssey or avoidance of further expensive or invasive investigations. Further studies are warranted to review how the diagnostic yield of aCGH has changed over time and altered clinical management, particularly in the context of newer sequencing technologies, which are increasingly being used in child neurology.

In our cohort of 555 patients, we have identified pathogenic CNVs in children with a wide spectrum of neurologic disorders. Our results support the more liberal (rather than restricted) use of aCGH technology as a first-tier investigation in patients with diverse neurologic conditions, particularly in those with complex neurologic phenotypes. Restricting the indication for testing to developmental delay or intellectual disability is likely to constrain the potential utility of this technology. In particular, our results indicate that the highest yield may be obtained in patients with a combination of developmental delay, dysmorphism, and microcephaly and those individuals with numerous neurologic comorbidities. Further studies using a consecutive cases approach and randomized allocation are warranted to substantiate these findings.

\section{Study funding}

No targeted funding reported.

\section{Disclosure}

Disclosures available: Neurology.org/NG.

\section{Publication history}

Received by Neurology: Genetics April 26, 2019. Accepted in final form August 28, 2019.

\begin{tabular}{|c|c|c|c|}
\hline Name & Location & Role & Contribution \\
\hline $\begin{array}{l}\text { Shibalik } \\
\text { Misra, MBBS/ } \\
\text { MPhil }\end{array}$ & $\begin{array}{l}\text { Kids Neuroscience } \\
\text { Centre, the } \\
\text { Children's Hospital at } \\
\text { Westmead, Faculty of } \\
\text { Medicine and Health, } \\
\text { The University of } \\
\text { Sydney }\end{array}$ & Author & $\begin{array}{l}\text { Designed and } \\
\text { conceptualized the } \\
\text { study, major role in } \\
\text { the acquisition of } \\
\text { data, and drafted the } \\
\text { manuscript for } \\
\text { intellectual content }\end{array}$ \\
\hline $\begin{array}{l}\text { Greg Peters, } \\
\text { PhD }\end{array}$ & $\begin{array}{l}\text { Department of } \\
\text { Clinical Genetics at } \\
\text { The Children's } \\
\text { Hospital at } \\
\text { Westmead }\end{array}$ & Author & $\begin{array}{l}\text { Analyzed the data } \\
\text { and revised the } \\
\text { manuscript for } \\
\text { intellectual content }\end{array}$ \\
\hline $\begin{array}{l}\text { Elizabeth } \\
\text { Barnes, } \\
\text { BAppSc/ } \\
\text { MStat }\end{array}$ & $\begin{array}{l}\text { Kids Research } \\
\text { Institute at } \\
\text { Westmead }\end{array}$ & Author & $\begin{array}{l}\text { Analyzed the data } \\
\text { and revised the } \\
\text { manuscript for } \\
\text { intellectual content }\end{array}$ \\
\hline $\begin{array}{l}\text { Simone } \\
\text { Ardern- } \\
\text { Holmes, PhD }\end{array}$ & $\begin{array}{l}\text { TY Nelson } \\
\text { Department of } \\
\text { Neurology and } \\
\text { Neurosurgery at The } \\
\text { Children's Hospital at } \\
\text { Westmead, Sydney, } \\
\text { New South Wales, } \\
\text { Australia }\end{array}$ & Author & $\begin{array}{l}\text { Designed and } \\
\text { conceptualized the } \\
\text { study, role in the } \\
\text { acquisition of data, } \\
\text { and revised the } \\
\text { manuscript for } \\
\text { intellectual content }\end{array}$ \\
\hline
\end{tabular}

Continued 
Appendix (continued)

\begin{tabular}{|c|c|c|c|}
\hline Name & Location & Role & Contribution \\
\hline $\begin{array}{l}\text { Richard } \\
\text { Webster, } \\
\text { FRACP }\end{array}$ & $\begin{array}{l}\text { TY Nelson } \\
\text { Department of } \\
\text { Neurology and } \\
\text { Neurosurgery at The } \\
\text { Children's Hospital at } \\
\text { Westmead, Sydney, } \\
\text { New South Wales, } \\
\text { Australia }\end{array}$ & Author & $\begin{array}{l}\text { Role in the } \\
\text { acquisition of data } \\
\text { and revised the } \\
\text { manuscript for } \\
\text { intellectual content }\end{array}$ \\
\hline $\begin{array}{l}\text { Christopher } \\
\text { Troedson, } \\
\text { FRACP }\end{array}$ & $\begin{array}{l}\text { TY Nelson } \\
\text { Department of } \\
\text { Neurology and } \\
\text { Neurosurgery at The } \\
\text { Children's Hospital at } \\
\text { Westmead, Sydney, } \\
\text { New South Wales, } \\
\text { Australia }\end{array}$ & Author & $\begin{array}{l}\text { Role in the } \\
\text { acquisition of data } \\
\text { and revised the } \\
\text { manuscript for } \\
\text { intellectual content }\end{array}$ \\
\hline $\begin{array}{l}\text { Shekeeb S. } \\
\text { Mohammad, } \\
\text { PhD }\end{array}$ & $\begin{array}{l}\text { TY Nelson } \\
\text { Department of } \\
\text { Neurology and } \\
\text { Neurosurgery at The } \\
\text { Children's Hospital at } \\
\text { Westmead, Sydney, } \\
\text { New South Wales, } \\
\text { Australia }\end{array}$ & Author & $\begin{array}{l}\text { Revised the } \\
\text { manuscript for } \\
\text { intellectual content }\end{array}$ \\
\hline $\begin{array}{l}\text { Deepak Gill, } \\
\text { FRACP }\end{array}$ & $\begin{array}{l}\text { TY Nelson } \\
\text { Department of } \\
\text { Neurology and } \\
\text { Neurosurgery at The } \\
\text { Children's Hospital at } \\
\text { Westmead, Sydney, } \\
\text { New South Wales, } \\
\text { Australia }\end{array}$ & Author & $\begin{array}{l}\text { Role in the } \\
\text { acquisition of data } \\
\text { and revised the } \\
\text { manuscript for } \\
\text { intellectual content }\end{array}$ \\
\hline $\begin{array}{l}\text { Manoj } \\
\text { Menezes, } \\
\text { PhD }\end{array}$ & $\begin{array}{l}\text { TY Nelson } \\
\text { Department of } \\
\text { Neurology and } \\
\text { Neurosurgery at The } \\
\text { Children's Hospital at } \\
\text { Westmead, Sydney, } \\
\text { New South Wales, } \\
\text { Australia }\end{array}$ & Author & $\begin{array}{l}\text { Role in the } \\
\text { acquisition of data } \\
\text { and revised the } \\
\text { manuscript for } \\
\text { intellectual content }\end{array}$ \\
\hline $\begin{array}{l}\text { Sachin } \\
\text { Gupta, } \\
\text { FRACP }\end{array}$ & $\begin{array}{l}\text { TY Nelson } \\
\text { Department of } \\
\text { Neurology and } \\
\text { Neurosurgery at The } \\
\text { Children's Hospital at } \\
\text { Westmead, Sydney, } \\
\text { New South Wales, } \\
\text { Australia }\end{array}$ & Author & $\begin{array}{l}\text { Role in the } \\
\text { acquisition of data } \\
\text { and revised the } \\
\text { manuscript for } \\
\text { intellectual content }\end{array}$ \\
\hline $\begin{array}{l}\text { Peter } \\
\text { Procopis, } \\
\text { FRACP }\end{array}$ & $\begin{array}{l}\text { TY Nelson } \\
\text { Department of } \\
\text { Neurology and } \\
\text { Neurosurgery at The } \\
\text { Children's Hospital at } \\
\text { Westmead, Sydney, } \\
\text { New South Wales, } \\
\text { Australia }\end{array}$ & Author & $\begin{array}{l}\text { Role in the } \\
\text { acquisition of data } \\
\text { and revised the } \\
\text { manuscript for } \\
\text { intellectual content }\end{array}$ \\
\hline $\begin{array}{l}\text { Jayne } \\
\text { Antony, } \\
\text { FRACP }\end{array}$ & $\begin{array}{l}\text { TY Nelson } \\
\text { Department of } \\
\text { Neurology and } \\
\text { Neurosurgery at The } \\
\text { Children's Hospital at } \\
\text { Westmead, Sydney, } \\
\text { New South Wales, } \\
\text { Australia }\end{array}$ & Author & $\begin{array}{l}\text { Role in the } \\
\text { acquisition of data } \\
\text { and revised the } \\
\text { manuscript for } \\
\text { intellectual content }\end{array}$ \\
\hline $\begin{array}{l}\text { Manju A. } \\
\text { Kurian, PhD }\end{array}$ & $\begin{array}{l}\text { Institute of Child } \\
\text { Health, University } \\
\text { College London, UK }\end{array}$ & Author & $\begin{array}{l}\text { Revised the } \\
\text { manuscript for } \\
\text { intellectual content }\end{array}$ \\
\hline
\end{tabular}

Appendix (continued)

\begin{tabular}{|c|c|c|c|}
\hline Name & Location & Role & Contribution \\
\hline $\begin{array}{l}\text { Russell C } \\
\text { Dale, PhD }\end{array}$ & $\begin{array}{l}\text { TY Nelson } \\
\text { Department of } \\
\text { Neurology and } \\
\text { Neurosurgery at The } \\
\text { Children's Hospital at } \\
\text { Westmead, Sydney, } \\
\text { New South Wales, } \\
\text { Australia }\end{array}$ & Author & $\begin{array}{l}\text { Designed and } \\
\text { conceptualized the } \\
\text { study, role in the } \\
\text { acquisition of data, } \\
\text { and revised the } \\
\text { manuscript for } \\
\text { intellectual } \\
\text { content }\end{array}$ \\
\hline
\end{tabular}

\section{References}

1. Scherer SW, Lee C, Birneyx E, et al. Challenges and standards in integrating surveys of structural variation. Nat Genet 2007;39:S7-S15.

2. Redon R, Ishikawa $S$, Fitch KR, et al. Global variation in copy number in the human genome. Nature 2006;444:444-454.

3. Itsara A, Cooper GM, Baker C, et al. Population analysis of large copy number variants and hotspots of human genetic disease. Am J Hum Genet 2009;84:148-161.

4. de Vries BB, Pfundt R, Leisink M, et al. Diagnostic genome profiling in mental retardation. Am J Hum Genet 2005;77:606-616.

5. Menten B, Maas N, Thienpont B, et al. Emerging patterns of cryptic chromosomal imbalance in patients with idiopathic mental retardation and multiple congenital anomalies: a new series of 140 patients and review of published reports. J Med Genet 2006;43:625-633.

6. Fan YS, Jayakar P, Zhu H, et al. Detection of pathogenic gene copy number variations in patients with mental retardation by genomewide oligonucleotide array comparative genomic hybridization. Hum Mutat 2007;28:1124-1132.

7. Hoyer J, Dreweke A, Becker C, et al. Molecular karyotyping in patients with mental retardation using 100k single-nucleotide polymorphism arrays. J Med Genet 2007;44: 629-636.

8. Pickering DL, Eudy JD, Olney AH, et al. Array-based comparative genomic hybridization analysis of 1176 consecutive clinical genetics investigations. Genet Med 2008; 10:262-266.

9. Friedman JM, Adam S, Arbour L, et al. Detection of pathogenic copy number variants in children with idiopathic intellectual disability using $500 \mathrm{~K}$ SNP array genomic hybridization. BMC Genomics 2009;10:526.

10. Gijsbers AC, Lew JY, Bosch CA, et al. A new diagnostic workflow for patients with mental retardation and/or multiple congenital abnormalities: test arrays first. Eur J Hum Genet 2009; 17:1394-1402.

11. Qiao Y, Harvard C, Tyson C, et al. Outcome of array CGH analysis for 255 subjects with intellectual disability and search for candidate genes using bioinformatics. Hum Genet 2010;128:179-194.

12. Xiang B, Zhu H, Shen $\mathrm{Y}$, et al. Genome-wide olignucleotide array comparative genomic hybridization for etiological diagnosis of mental retardation. J Mol Diagn 2010; 12:204-212.

13. Siggberg L, Ala-Mello S, Jaakkola E, et al. Array CGH in molecular diagnosis of mental retardation-a study of 150 Finnish patients. Am J Med Genet A 2010;152A: 1398-1410.

14. Hayashi S, Imoto I, Aizu Y, et al. Clinical application of array-based comparative genomic hybridization by two-stage screening for 536 patients with mental retardation and multiple congenital anomalies. J Hum Genet 2011;56:110-124.

15. Wincent J, Anderlid BM, Lagerberg M, Nordenskjöld M, Schoumans J. High resolution molecular karyotyping in patients with developmental delay and/or multiple congenital anomalies in a clinical setting. Clin Genet 2011;79:147-157.

16. Filges I, Suda L, Weber P, et al. High resolution array in the clinical approach to chromosomal phenotypes. Gene 2012;495:163-169.

17. Lee CG, Park SJ, Yun JN, et al. Array-based comparative genomic hybridization in 190 Korean patients with developmental delay and/or intellectual disability: a single tertiary care university center study. Yonsei Med J 2013;54:1463-1470.

18. Nicholl J, Waters W, Mulley JC, et al. Cognitive deficit and autism spectrum disorders: prospective diagnosis by array CGH. Pathology 2014:46:41-45.

19. Henderson LB, Applegate CD, Wohler E, Sheridan MB, Hoover-Fong J, Batista DA. The impact of chromosomal microarray on clinical management: a retrospective analysis. Genet Med 2014;16:657-664.

20. Ho KS, Wassman ER, Baxter AL, et al. Chromosomal microarray analysis of consecutive individuals with autism spectrum disorders using an ultra-high resolution chromosomal microarray optimized for neurodevelopmental disorders. Int J Mol Med Sci 2016; $17: 2070$

21. D'Arrigo S, Gavazzi F, Alfei E, et al. The diagnostic yield of array comparative genomic hybridization is high regardless of severity of intellectual disability/developmental delay in children. J Child Neurol 2016;31:691-699.

22. Pfundt R, Kwiatkowski K, Roter A, et al. Clinical performance of the CytoScan Dx assay in diagnosing developmental delay/intellectual disability. Genet Med 2016;18: $168-173$. 
23. Quintela I, Eirís J, Gómez-Lado C, et al. Copy number variation analysis of patients with intellectual disability from North-West Spain. Gene 2017;626:189-199.

24. Mefford HC, Yendle SC, Hsu C, et al. Rare copy number variants are an important cause of epileptic encephalopathies. Ann Neurol 2011;70:974-985.

25. Bartnik M, Szczepanik E, Derwińska K, et al. Application of array comparative genomic hybridization in 102 patients with epilepsy and additional neurodevelopmental disorders. Am J Med Genet B Neuropsychiatr Genet 2012;159B:760-771.

26. Nicholl J, Waters W, Suwalski S, et al. Epilepsy with cognitive deficit and autism spectrum disorders: prospective diagnosis by array CGH. Am J Med Genet Part B Neuropsychiatr Genet 2013;162B:24-35.
27. Olson $\mathrm{H}$, Shen $\mathrm{Y}$, Avallone J, et al. Copy number variation plays an important role in clinical epilepsy. Ann Neurol 2014;75:943-958.

28. Hrabik SA, Standridge SM, Greiner HM, et al. The clinical utility of a singlenucleotide polymorphism microarray in patients with epilepsy at a tertiary medical center. J Child Neurol 2015;30:1770-1777.

29. Beaudet AL. Reaching a CNV milestone. Nat Genet 2014;46:1046-1048.

30. Kent WJ, Sugnet CW, Furey TS, et al. The human genome browser at UCSC. Genome Res 2002;12:996-1006.

31. Howell KB, Kornberg AJ, Harvey AS, et al. High resolution chromosomal microarray in undiagnosed neurological disorders. J Paediatric Child Health 2013;49:716-724. 


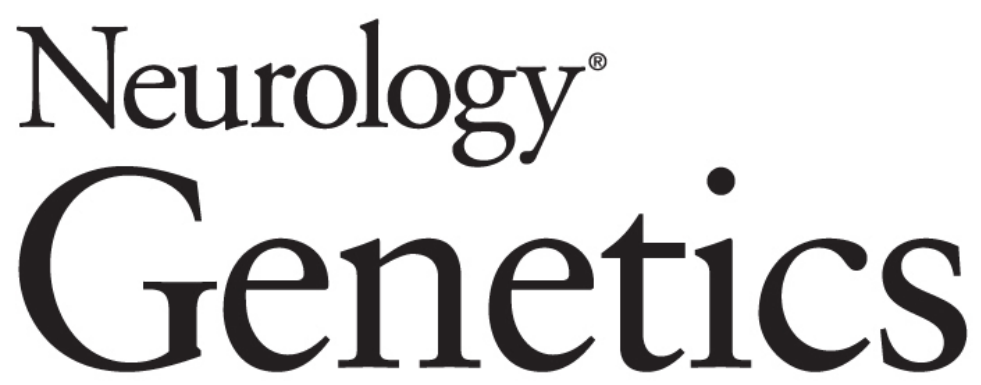

Yield of comparative genomic hybridization microarray in pediatric neurology practice Shibalik Misra, Greg Peters, Elizabeth Barnes, et al.

Neurol Genet 2019;5;

DOI 10.1212/NXG.0000000000000367

This information is current as of October 23, 2019

Neurol Genet is an official journal of the American Academy of Neurology. Published since April 2015, it is an open-access, online-only, continuous publication journal. Copyright Copyright $@ 2019$ The Author(s). Published by Wolters Kluwer Health, Inc. on behalf of the American Academy of Neurology.. All rights reserved. Online ISSN: 2376-7839.

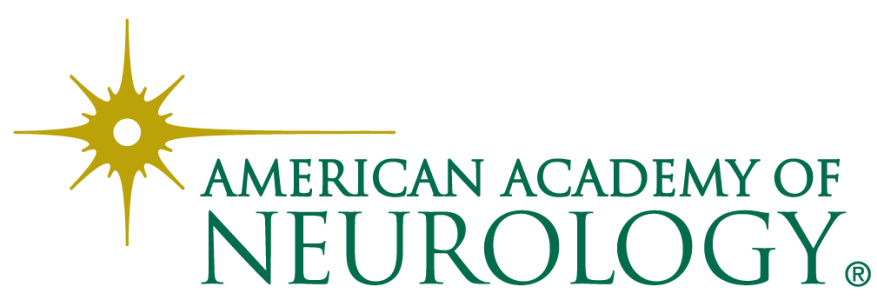




\section{Updated Information \& Services}

References

\section{Subspecialty Collections}

\section{Permissions \& Licensing}

\section{Reprints}

including high resolution figures, can be found at: http://ng.neurology.org/content/5/6/e367.full.html

This article cites 31 articles, 3 of which you can access for free at: http://ng.neurology.org/content/5/6/e367.full.html\#\#ref-list-1

This article, along with others on similar topics, appears in the following collection(s):

All Clinical Neurology

http://ng.neurology.org//cgi/collection/all_clinical_neurology

All Epilepsy/Seizures

http://ng.neurology.org//cgi/collection/all_epilepsy_seizures

All Genetics

http://ng.neurology.org//cgi/collection/all_genetics

All Pediatric

http://ng.neurology.org//cgi/collection/all_pediatric

Antiepileptic drugs

http://ng.neurology.org//cgi/collection/antiepileptic_drugs

Developmental disorders

http://ng.neurology.org//cgi/collection/developmental_disorders

Infantile spasms

http://ng.neurology.org//cgi/collection/infantile_spasms

Ion channel gene defects

http://ng.neurology.org//cgi/collection/ion_channel_gene_defects

Neonatal seizures

http://ng.neurology.org//cgi/collection/neonatal_seizures

Information about reproducing this article in parts (figures,tables) or in its entirety can be found online at:

http://ng.neurology.org/misc/about.xhtml\#permissions

Information about ordering reprints can be found online:

http://ng.neurology.org/misc/addir.xhtml\#reprintsus

Neurol Genet is an official journal of the American Academy of Neurology. Published since April 2015, it is an open-access, online-only, continuous publication journal. Copyright Copyright $\odot 2019$ The Author(s). Published by Wolters Kluwer Health, Inc. on behalf of the American Academy of Neurology.. All rights reserved. Online ISSN: 2376-7839.

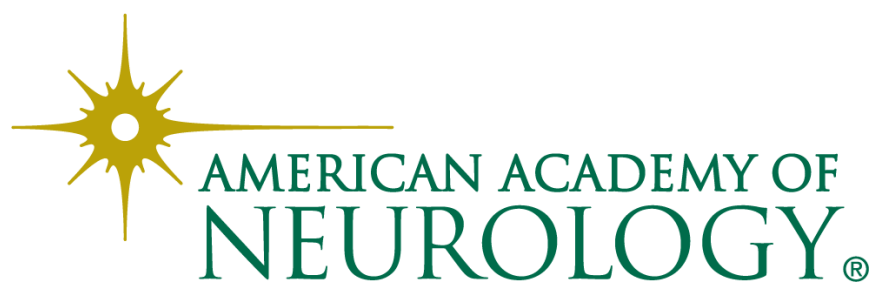

